\title{
Fraksi fosfor tanah pada lapisan olah dan korelasinya dengan beberapa sifat kimia tanah hutan dan perkebunan kelapa sawit di Jambi
}

\author{
Soil phosphorus fractions in top soil and its correlation with some soil chemical properties of forest \\ and oil palm plantations in Jambi
}

\author{
Natalia D. D. Ndua ${ }^{\mathrm{a}}$, Arief Hartono ${ }^{\mathrm{b}}$, Syaiful Anwar ${ }^{\mathrm{b}}$, Budi Nugroho $^{\mathrm{b}}$ \\ ${ }^{a}$ Program Studi Ilmu Tanah, Sekolah Pascasarjana, Institut Pertanian Bogor, Kampus IPB Darmaga Bogor, 16680, Indonesia \\ [+6285237058746] \\ ${ }^{\mathrm{b}}$ Departemen Ilmu Tanah dan Sumberdaya Lahan, Fakultas Pertanian, Institut Pertanian Bogor, Kampus IPB Darmaga Bogor, 16680 , \\ Indonesia
}

Article Info:

Received: 23 - 12 - 2019

Accepted: 19 - 05 - 2020

Keywords:

Horizon, land use, organic C, P

dynamic, rainforest

Corresponding Author:

Arief Hartono

Departemen Ilmu Tanah dan

Sumberdaya Lahan, Fakultas

Pertanian, Institut Pertanian

Bogor, Kampus IPB Darmaga

Bogor;

Tel. +628121108782

Email:

hartono@apps.ipb.ac.id

\begin{abstract}
The change from forest to oil palm plantation probably changes the distribution of phosphorus $(P)$ fractions in the soil. This study aimed to evaluate the soil top layer $P$ fractions, collected in forest and oil palm plantation in Jambi, as well as their correlation with soil chemical properties. Soil samples were collected in top layers of forest and oil palm plantation. Some soil chemical properties and P fractions were analyzed. The P fractions analyses were conducted according to Tiessen and Moir method. The results showed that the moderately labile $P$ fractions namely $\mathrm{NaOH}-P_{\text {organic }}\left(-P_{o}\right)$ and $-P_{\text {inorganic }}(P i)$ were the dominant fraction in forest soil and oil palm plantation as well. The forest had a higher percentage of available $P$ (resin- $P_{i}, \mathrm{NaHCO} 3-$ $\left.P_{i},-P_{o}\right)$ and organic moderately labile $P\left(N a O H-P_{o}\right)$ compared to those of oil palm plantations in their total fractions analyzed. As for $\mathrm{NaOH}-\mathrm{P}_{i}$, oil palm plantation had a higher amount of this fraction compared to that of the forest. This means that naturally the change from forest to oil palm plantation changed the $P$ fractions distribution due to the changes of organic carbon $(C)$ content. The correlation test showed that almost all $P$ fractions significantly positively correlated with organic $C$ suggested that the organic $C$ content increased $P$ fractions. This showed that organic $C$ controlled the $P$ fractions distribution in the topsoil of forest and oil palm plantation.
\end{abstract}

How to cite (CSE Style $8^{\text {th }}$ Edition):

Ndua NDD, Hartono A, Anwar S, Nugroho B. 2020. Fraksi fosfor pada lapisan olah dan korelasinya dengan beberapa sifat kimia tanah di Jambi. JPSL 10(2): 209-219. http://dx.doi.org/10.29244/jpsl.10.2.209-219.

\section{PENDAHULUAN}

Perubahan penggunaan lahan dari lahan hutan ke perkebunan kelapa sawit sudah dilakukan sejak pertengahan abad ke-20, termasuk di Jambi (Drescher et al., 2016). Hal tersebut menguntungkan bagi pemenuhan kebutuhan hidup manusia dalam jangka waktu pendek namun tidak dengan keberlanjutan ekosistem. Kehilangan bahan organik tanah dan unsur hara termasuk cadangan fosfor $(\mathrm{P})$ di tanah telah dilaporkan sebelumnya dalam penelitian Maranguit et al. (2017). Konfirmasi mengenai hasil penelitian tersebut perlu untuk dilakukan. Tiessen dan Moir (1993) menyatakan bahwa $\mathrm{P}$ adalah salah satu nutrisi terpenting yang mengendalikan produksi biomassa tanaman dan terdiri atas bentuk $\mathrm{P}_{\text {organik }}\left(\mathrm{P}_{\mathrm{o}}\right)$ dan $\mathrm{P}_{\text {inorganik }}\left(\mathrm{P}_{\mathrm{i}}\right)$ yang umumnya terdapat dalam fraksi tersedia (labil) dan agak labil. Kadar bahan organik, keberadaan 
aluminium ( $\mathrm{Al}$ ) dan besi ( $\mathrm{Fe}$ ) hidrusoksida, serta $\mathrm{pH}$ tanah mempengaruhi ketersediaan $\mathrm{P}$ di tanah bagi tanaman (Tiecher et al., 2018; Hartono et al., 2006). Pada tanah masam keberadaan Al dan Fe hidrusoksida yang cukup tinggi akan mengikat $\mathrm{P}$ sehingga menjadikan $\mathrm{P}$ tidak tersedia bagi tanaman.

Penggunaan lahan yang berbeda diduga memiliki jumlah dan distribusi $\mathrm{P}$ yang berbeda pula termasuk faktor yang paling mempengaruhinya. Beberapa metode fraksionasi $\mathrm{P}$ telah dikembangkan untuk mempelajari bentuk-bentuk, jumlah, dan distribusi P (Tiessen dan Moir, 1993; Hedley et al., 1982; Chang dan Jackson, 1957; Hartono et al., 2006). Bentuk P inorganik mendominasi (60-85\%) dari seluruh total P baik pada lahan agroforestri karet maupun pada lahan monokultur karet dan monokultur kelapa sawit, sedangkan $\mathrm{P}$ organik lebih besar jumlahnya di lahan agroforestri karet (Maranguit et al., 2017). Akumulasi bahan organik tanah di lapisan permukaan dapat meningkatkan akumulasi P organik di tanah hutan, sedangkan bahan organik tanah yang sedikit di tanah berpasir atau tanah lahan pertanian menyebabkan P organik berada dalam jumlah yang sedikit (Hou et al., 2014).

Kelapa sawit merupakan salah satu komoditas andalan di Indonesia. Berdasarkan data BPS (2018) kawasan kelapa sawit di Indonesia adalah seluas 12.7 juta hektar dengan total produksi minyak sawit mencapai 36.5 juta ton. Hanum et al. (2016) menyatakan bahwa P merupakan salah satu unsur hara yang sangat dibutuhkan kelapa sawit untuk dapat bertumbuh dengan baik dan menghasilkan produksi yang maksimal. Setelah hutan dijadikan perkebunan kelapa sawit diduga fraksi $\mathrm{P}$ tanah berubah dari kondisi alaminya, sehingga perlu dilakukan suatu kajian untuk mengetahui seberapa besar perubahannya dan faktor yang mempengaruhinya.

Secara umum distribusi P di tanah-tanah masam lahan kering di Indonesia sangat dipengaruhi oleh keberadaan hidrusoksida $\mathrm{Al}$ dan Fe (Hartono et al., 2005; 2006), walaupun demikian perlu dikaji lebih detail sifat-sifat tanah yang mempengaruhi distribusi fraksi $\mathrm{P}$ pada lapisan atas tanah dimana terjadi dinamika kandungan $\mathrm{C}$ organik karena pengelolaan tanah. Penelitian ini bertujuan untuk mengevaluasi fraksi-fraksi $\mathrm{P}$ tanah pada lapisan atas dan untuk mengkaji hubungan fraksi P dengan beberapa sifat kimia tanah di lahan hutan dan perkebunan kelapa sawit di Jambi.

\section{METODE}

\section{Lokasi dan Waktu Penelitian}

Penelitian ini dilakukan pada bulan Mei hingga Oktober 2019. Analisis contoh tanah dilakukan di Laboratorium Kimia dan Kesuburan Tanah, Departemen Ilmu Tanah dan Sumberdaya Lahan, Institut Pertanian Bogor dan Laboratorium Penguji Balai Penelitian Tanah, Badan Penelitian dan Penggembangan Pertanian, Bogor. Contoh tanah diperoleh dari penggunaan lahan Hutan Harapan dan perkebunan kelapa sawit di Kecamatan Bajubang, Kabupaten Batang Hari, Provinsi Jambi. Masing-masing penggunaan lahan terdiri dari tiga titik profil tanah. Koordinat titik profil tanah pada penggunaan lahan hutan adalah hutan 1

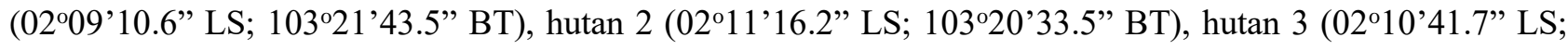
$103^{\circ} 19^{\prime} 58.9^{\prime \prime}$ BT) sedangkan perkebunan kelapa sawit adalah sawit 1 (01 ${ }^{\circ} 54^{\prime} 7^{\prime \prime}$ ' LS; $103^{\circ} 15^{\prime} 59.4^{\prime \prime}$ BT), sawit 2 (01 $53^{\circ} 00.5^{\prime \prime}$ LS; $103^{\circ} 16^{\prime} 01.4^{\prime \prime}$ BT), sawit 3 (01 ${ }^{\circ} 54^{\prime} 33.6^{\prime \prime}$ LS; 10315'59.6” BT). Posisi profil tanah disajikan dalam Gambar 1. 


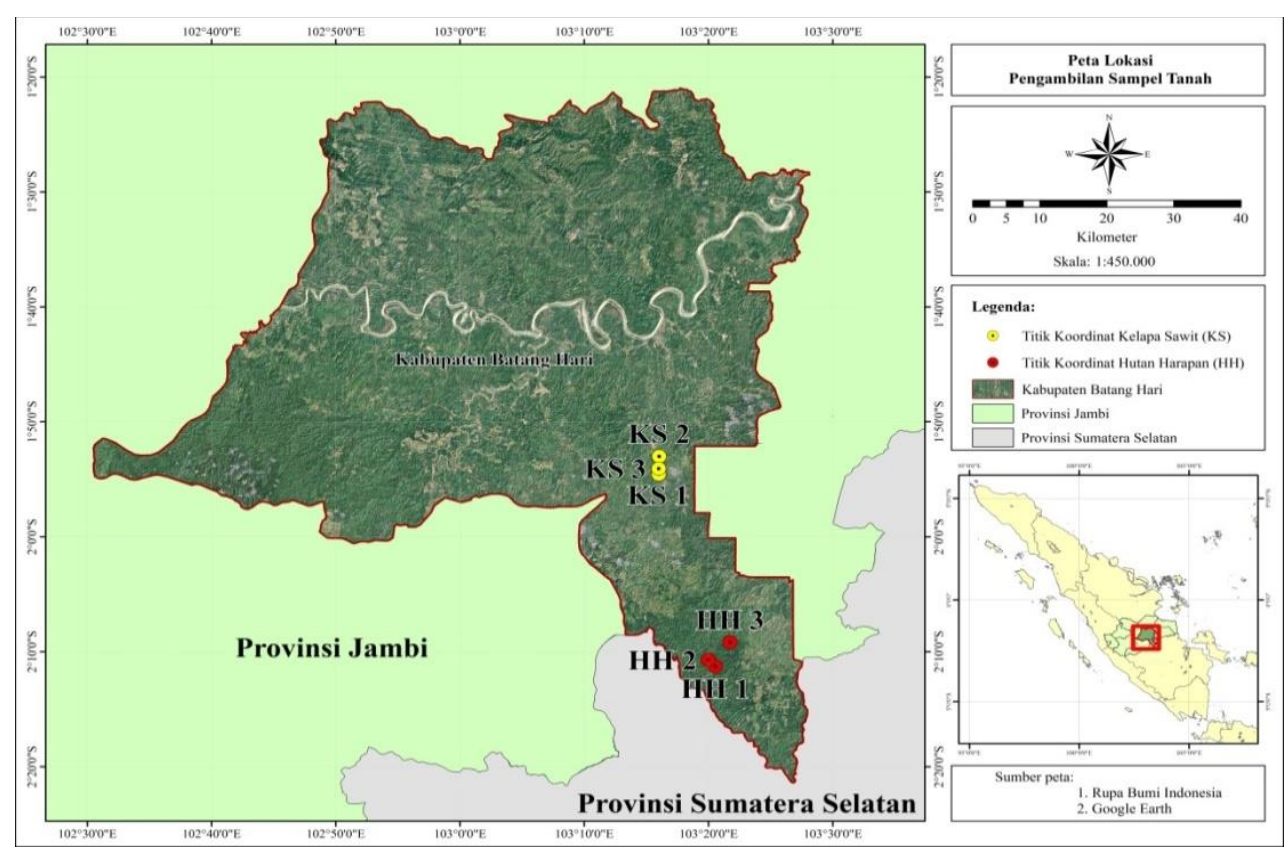

Gambar 1 Posisi profil tanah pada penggunaan lahan hutan dan perkebunan kelapa sawit (KS: titik profil pada perkebunan kelapa sawit, $\mathrm{HH}$ : titik profil pada hutan)

\section{Bahan dan Metode Analisis Tanah}

Contoh tanah diwakili oleh 3 profil tanah di lahan hutan dan 3 profil tanah di perkebunan kelapa sawit. Contoh tanah diambil secara komposit pada kedalaman tanah berdasarkan horison tanah (Ah, A, dan E). Horison Ah merupakan horison mineral yang didominasi oleh bahan organik, horison A merupakan horison mineral dengan akumulasi bahan organik halus yang tercampur dengan bahan mineral, dan horison $\mathrm{E}$ adalah horison mineral dengan sifat utama terjadi pencucian bahan organik dan liat. Setiap titik profil tanah memiliki kedalaman horison tanah yang berbeda. Pengambilan contoh tanah di perkebunan kelapa sawit dilakukan di gawangan hidup bukan di piringan tempat pemupukan atau di gawangan mati tempat penumpukan pelepahpelepah sawit untuk mewakili contoh tanah yang mewakili perubahan penggunaan lahan dari hutan ke perkebunan kelapa sawit.

Contoh tanah dikeringudarakan selama 3 hari. Kemudian tanah dihaluskan hingga lolos saringan $0.5 \mathrm{~mm}$ untuk selanjutnya dilakukan analisis. Sifat kimia tanah terpilih yang dianalisis adalah $\mathrm{pH}_{2} \mathrm{O}$ (1:5), karbon organik (C-organik) (Walkley dan Black), $\mathrm{Al}$ dan Fe hidrusoksida ekstrak dithionit sitrat bikarbonat (DCB) $\left(\mathrm{Al}_{\mathrm{d}}\right.$ dan $\left.\mathrm{Fe}_{\mathrm{d}}\right)$ dengan metode Mehra dan Jackson (1960), Al dan $\mathrm{Fe}$ amorf ekstrak amonium oksalat $\left(\mathrm{Al}_{\mathrm{o}}\right.$ dan $\mathrm{Fe}_{\mathrm{o}}$ ) dengan metode McKeague dan Day (1966). Fraksi P tanah ditentukan berdasarkan bahan pengekstraknya dengan menggunakan metode Tiessen dan Moir (1993), yaitu: (1) resin- $\mathrm{P}_{\mathrm{i}}$ yang dijenuhi $\mathrm{NaHCO}_{3}$ dan $\mathrm{NaHCO}_{3}-\mathrm{P}_{\mathrm{i}},-\mathrm{P}_{\mathrm{o}}$ (P yang labil), (2) NaOH-$-\mathrm{P}_{\mathrm{i}},-\mathrm{P}_{\mathrm{o}}$ dan $\mathrm{HCl}-\mathrm{P}_{\mathrm{i}}(\mathrm{P}$ agak labil). Prosedur fraksionasi $\mathrm{P}$ secara ringkas disajikan dalam Gambar 2.

\section{Metode Analisis Data}

Pengolahan data dilakukan dengan menggunakan aplikasi Software Microsoft Office Excel dan SPSS 21. Software Microsoft Office Excel digunakan untuk perhitungan distribusi fraksi $\mathrm{P}$ tanah dan untuk membandingkan fraksi $\mathrm{P}$ antara hutan dan sawit dilakukan dengan cara merata-ratakan nilai persentase dari setiap titik profil tanah pada masing-masing penggunaan lahan. Nilai persentase pada Tabel 2 merupakan persentase setiap fraksi $\mathrm{P}$ terhadap nilai total $\mathrm{P}$ yang merupakan total dari seluruh fraksi yang dianalisis (per horison). Analisis korelasi Pearson digunakan untuk mengevaluasi sifat kimia tanah yang berpengaruh terhadap fraksi-fraksi P menggunakan SPSS 21. 


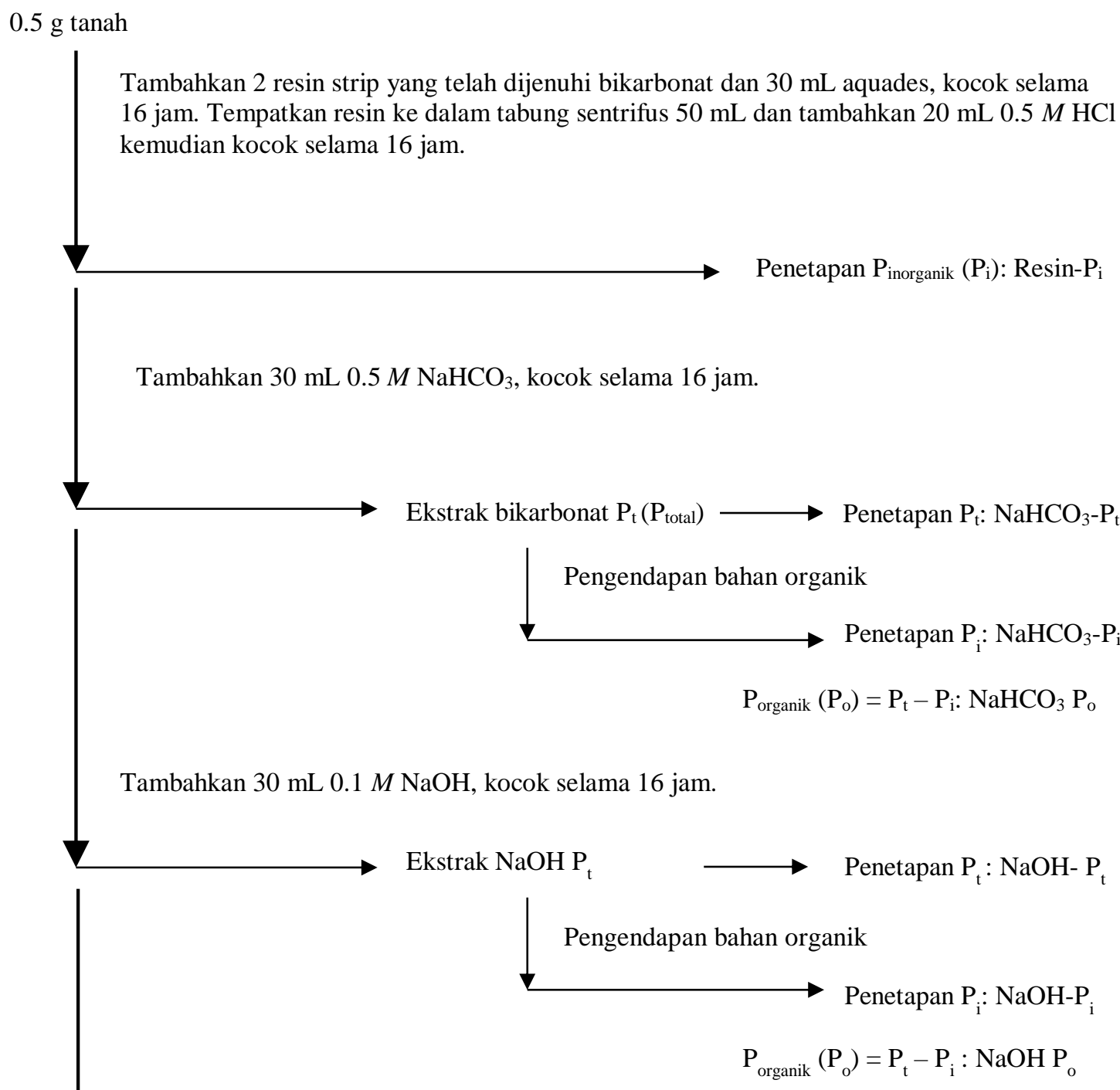

Tambahkan $30 \mathrm{~mL} 1 \mathrm{M} \mathrm{HCl}$, kocok selama 16 jam.

Ekstrak $\mathrm{HCl} \mathrm{P}_{\mathrm{i}}$

Penetapan $\mathrm{P}_{\mathrm{i}}$ : HCl- $\mathrm{P}_{\mathrm{i}}$

Gambar 2 Prosedur fraksionasi P (Tiessen dan Moir, 1993) modifikasi Hartono et al. (2006)

\section{HASIL DAN PEMBAHASAN}

\section{Sifat Kimia Tanah}

Data sifat kimia tanah disajikan pada Tabel 1. Data $\mathrm{pH}_{2} \mathrm{O}$ tanah secara umum pada lahan hutan maupun sawit pada semua titik profil tanah tergolong sangat masam. Intensitas curah hujan yang tinggi mengakibatkan tingkat pencucian basa di dalam tanah cukup intensif (Putra et al., 2019), sehingga kandungan basa-basa rendah dan tanah bereaksi masam (Subagyo et al., 2000). Secara umum kandungan C-organik menurun dengan kedalaman horison tanah pada seluruh titik profil di lahan hutan maupun sawit. Dibandingkan dengan tanah di sawit maka hutan memiliki kandungan C-organik tanah yang lebih tinggi pada horison Ah, sedangkan pada horison di bawahnya cenderung sama antara hutan dan sawit. Hal ini menunjukkan bahwa penurunan kandungan C-organik setelah lahan hutan dikonversi ke sawit pada penelitian ini hanya terjadi pada kedalaman tanah yang relatif kecil yakni berkisar 0 hingga $5 \mathrm{~cm}$. Schroth et al. (2002) melaporkan bahwa di bawah 
kedalaman $10 \mathrm{~cm}$ C-organik tidak ada perbedaan yang signifikan dan sebagian besar bahan organik tanah terkonsentrasi pada permukaan tanah. Bahan organik pada lahan sawit berasal dari rumput-rumput yang tumbuh di sekitar gawangan hidup, sedangkan lahan hutan secara alami berasal dari dari serasah vegetasi yang beragam di sekitarnya.

Ekstraksi DCB dalam penelitian ini digunakan untuk menentukan jumlah hidrusoksida $\mathrm{Al}$ dan $\mathrm{Fe}$ yang kristalin $\left(\mathrm{Al}_{\mathrm{d}}\right.$ dan $\left.\mathrm{Fe}_{\mathrm{d}}\right)$, sedangkan $\mathrm{Al}$ dan $\mathrm{Fe}$ yang diekstrak dengan amonium oksalat $\left(\mathrm{Al}_{\mathrm{o}}\right.$ dan $\left.\mathrm{Fe}_{\mathrm{o}}\right)$ digunakan untuk menentukan jumlah bentuk hidrusoksida $\mathrm{Al}$ dan Fe yang amorf. Berdasarkan Tabel 1 dapat dilihat bahwa $\mathrm{Al}_{\mathrm{d}}$ dan $\mathrm{Fe}_{\mathrm{d}}$ lebih tinggi nilainya dibandingkan $\mathrm{Al}_{\mathrm{o}}$ dan $\mathrm{Fe}_{\mathrm{o}}$. Hal ini mengindikasikan bahwa baik di lahan hutan maupun sawit bentuk $\mathrm{Al}$ dan Fe kristalin lebih dominan dibandingkan yang berbentuk amorf. Namun jika dibandingkan antara $\mathrm{Al}_{\mathrm{d}}$ dan $\mathrm{Fe}_{\mathrm{d}}$ maka $\mathrm{Fe}_{\mathrm{d}}$ lebih tinggi nilainya (0.62-1.71\%) dibandingkan $\mathrm{Al}_{\mathrm{d}}(0.13-0.32 \%)$. Bentuk Fe kristalin yang tinggi tersebut mencerminkan tanah sudah berkembang lanjut (Maharjan et al., 2018).

Tabel 1 Sifat kimia tanah pada penggunaan lahan hutan dan perkebunan kelapa sawit

\begin{tabular}{lcccccccc}
\hline \multirow{2}{*}{ Lahan } & \multirow{2}{*}{$\begin{array}{c}\text { Horison } \\
\text { Tanah }\end{array}$} & \multirow{2}{*}{$\begin{array}{c}\text { Kedalaman } \\
(\mathrm{cm})\end{array}$} & $\mathrm{pH} \mathrm{H} \mathrm{O}$ & $\mathrm{C}$-organik & \multicolumn{2}{c}{$\mathrm{DCB}$} & \multicolumn{3}{c}{ Oksalat } \\
\cline { 6 - 9 } & & & $\%$ & & $\%$ & $\mathrm{Fl}_{\mathrm{d}}$ & $\mathrm{Fe}_{\mathrm{o}}$ & $\mathrm{Al}_{\mathrm{o}}$ \\
\hline Hutan 1 & $\mathrm{Ah}$ & $0-2$ & 3.85 & 3.78 & 0.86 & 0.23 & 0.22 & 0.10 \\
& $\mathrm{~A}$ & $2-12$ & 4.00 & 1.53 & 1.10 & 0.22 & 0.28 & 0.08 \\
Hutan 2 & $\mathrm{E}$ & $12-31$ & 4.52 & 0.85 & 1.12 & 0.19 & 0.25 & 0.10 \\
& $\mathrm{Ah}$ & $0-5$ & 4.13 & 4.24 & 1.17 & 0.20 & 0.30 & 0.14 \\
& $\mathrm{~A}$ & $5-12$ & 4.24 & 1.59 & 1.28 & 0.19 & 0.35 & 0.14 \\
Hutan 3 & $\mathrm{E}$ & $12-24$ & 4.20 & 0.96 & 1.46 & 0.22 & 0.24 & 0.14 \\
& $\mathrm{Ah}$ & $0-3$ & 4.04 & 2.67 & 0.74 & 0.09 & 0.19 & 0.07 \\
& $\mathrm{~A}$ & $3-11$ & 3.96 & 1.16 & 0.91 & 0.13 & 0.26 & 0.07 \\
Sawit 1 & $\mathrm{E}$ & $11-23$ & 4.20 & 0.93 & 1.12 & 0.16 & 0.21 & 0.08 \\
& $\mathrm{Ah}$ & $0-5$ & 4.27 & 2.21 & 1.25 & 0.22 & 0.22 & 0.12 \\
Sawit 2 & $\mathrm{A}$ & $5-11$ & 4.09 & 1.61 & 1.52 & 0.28 & 0.29 & 0.17 \\
& $\mathrm{E}$ & $11-27$ & 4.08 & 0.77 & 1.71 & 0.32 & 0.27 & 0.18 \\
& $\mathrm{Ah}$ & $0-5$ & 4.20 & 1.27 & 0.88 & 0.17 & 0.26 & 0.12 \\
Sawit 3 & $\mathrm{A}$ & $5-10$ & 4.18 & 1.04 & 1.15 & 0.21 & 0.26 & 0.13 \\
& $\mathrm{E}$ & $10-18$ & 4.45 & 0.77 & 1.22 & 0.23 & 0.28 & 0.12 \\
& $\mathrm{Ah}$ & $0-7$ & 3.87 & 1.67 & 0.62 & 0.24 & 0.16 & 0.10 \\
& $\mathrm{~A}$ & $7-13$ & 3.94 & 1.37 & 0.72 & 0.24 & 0.17 & 0.10 \\
& $\mathrm{E}$ & $13-27$ & 3.96 & 1.39 & 0.80 & 0.25 & 0.19 & 0.11 \\
\hline
\end{tabular}

\section{Fraksi P Labil}

Fraksi $\mathrm{P}$ labil merupakan fraksi $\mathrm{P}$ yang tersedia bagi tanaman, terdiri dari fraksi $\mathrm{P}$ yang diekstraksi dengan resin yang dijenuhi oleh $\mathrm{NaHCO}_{3}$ dan $0.5 \mathrm{MNaHCO}_{3}$. Resin- $\mathrm{P}_{\mathrm{i}}$ adalah fraksi $\mathrm{P}$ yang diinterpretasikan sebagai $\mathrm{P}$ yang sangat tersedia bagi tanaman. Fraksi $\mathrm{NaHCO}_{3}-\mathrm{P}_{\mathrm{i}},-\mathrm{P}_{\mathrm{o}}$ adalah $\mathrm{P}$ yang tersedia baik inorganik dan organik (asam ribonukleat dan gliserofosfat) yang teradsorpsi pada permukaan mineral $\mathrm{Al}$ dan $\mathrm{Fe}$ hidrusoksida yang kristalin (Tiessen dan Moir, 1993). Konsentrasi fraksi P labil setiap profil tanah disajikan pada Tabel 2.

Berdasarkan Tabel 2 secara umum konsentrasi resin- $\mathrm{P}_{\mathrm{i}}$ dan $\mathrm{NaHCO}_{3}-\mathrm{P}_{\mathrm{i}}, \mathrm{P}_{\mathrm{o}}$ pada horison Ah tanah hutan lebih besar dibanding dengan horison di bawahnya dan tanah sawit. Fraksi P labil pada horison Ah yang tinggi pada tanah hutan berasal dari pelepasan $\mathrm{P}$ oleh bahan organik di mana kandungan $\mathrm{C}$-organik tertinggi terdapat pada horison Ah tanah hutan (Tabel 1). Dalam penelitian Rodrigues et al. (2015) melaporkan bahwa lahan yang tidak diusahakan memiliki akumulasi $\mathrm{P}_{\mathrm{i}}$ dan $\mathrm{P}_{\mathrm{o}}$ lebih banyak pada horison permukaan tanah (Ah) dibanding lahan yang diolah secara konvensional. Dalam sistem alami di tanah yang sangat lapuk, sumber utama $\mathrm{P}$ adalah berasal dari mineralisasi bahan organik tanah (Maharjan et al., 2018). Kandungan bahan 
organik (sumber C) yang tinggi sebagai energi penting untuk mikroorganisme meningkatkan aktivitasnya di tanah. Aktivitas mikroba berkontribusi untuk meningkatkan mineralisasi bahan organik menghasilkan $\mathrm{P}_{\mathrm{o}}$ dan $P_{i}$ yang tersedia terutama di lapisan atas tanah (Maharjan et al., 2018). Pada tanah di perkebunan kelapa sawit $P_{i}$ fraksi labil berasal dari pemupukan sedangkan $P_{o}$ berasal dari rumput-rumput dan serasah sawit.

Tabel 2 Bentuk P labil dan agak labil dalam tanah pada setiap titik profil tanah di lahan hutan dan perkebunan kelapa sawit

\begin{tabular}{|c|c|c|c|c|c|c|c|c|c|c|c|c|c|}
\hline \multirow{4}{*}{ Lahan } & \multirow{4}{*}{$\begin{array}{l}\text { Hori- } \\
\text { son }\end{array}$} & \multicolumn{6}{|c|}{ P labil } & \multicolumn{6}{|c|}{$\mathrm{P}$ agak labil } \\
\hline & & \multirow{2}{*}{\multicolumn{2}{|c|}{$\begin{array}{c}\text { Resin } \\
P_{i}\end{array}$}} & \multicolumn{4}{|c|}{$\mathrm{NaHCO}_{3}-\mathrm{P}$} & \multicolumn{4}{|c|}{$\mathrm{NaOH}-\mathrm{P}$} & \multirow{2}{*}{\multicolumn{2}{|c|}{$\frac{\mathrm{HCl}-\mathrm{P}}{\mathrm{P}_{\mathrm{i}}}$}} \\
\hline & & & & \multicolumn{2}{|c|}{$P_{i}$} & \multicolumn{2}{|c|}{$\mathrm{P}_{\mathrm{o}}$} & \multicolumn{2}{|c|}{$P_{i}$} & \multicolumn{2}{|c|}{$\mathrm{P}_{\mathrm{o}}$} & & \\
\hline & & $\mathrm{ppm}$ & $\%$ & $\mathrm{ppm}$ & $\%$ & $\mathrm{ppm}$ & $\%$ & $\mathrm{ppm}$ & $\%$ & $\mathrm{ppm}$ & $\%$ & $\mathrm{ppm}$ & $\%$ \\
\hline \multirow[t]{3}{*}{ Hutan 1} & $\mathrm{Ah}$ & 7.69 & 9.25 & 3.99 & 4.80 & 8.27 & 9.95 & 19.74 & 23.76 & 41.01 & 49.35 & 2.41 & 2.90 \\
\hline & A & 3.49 & 6.42 & 3.30 & 6.07 & 2.79 & 5.13 & 12.03 & 22.12 & 31.40 & 57.74 & 1.37 & 2.52 \\
\hline & $\mathrm{E}$ & 3.17 & 10.11 & 3.83 & 12.23 & 0.99 & 3.16 & 10.72 & 34.19 & 11.97 & 38.21 & 0.66 & 2.11 \\
\hline \multirow[t]{3}{*}{ Hutan 2} & $\mathrm{Ah}$ & 7.21 & 12.55 & 3.41 & 5.93 & 5.74 & 9.99 & 12.74 & 22.18 & 26.92 & 46.88 & 1.41 & 2.46 \\
\hline & A & 4.49 & 13.65 & 2.71 & 8.25 & 4.11 & 12.51 & 7.81 & 23.74 & 12.71 & 38.65 & 1.05 & 3.20 \\
\hline & E & 3.13 & 14.12 & 0.31 & 1.40 & 4.21 & 19.02 & 5.01 & 22.61 & 9.49 & 42.85 & 0.00 & 0.00 \\
\hline \multirow[t]{3}{*}{ Hutan 3} & $\mathrm{Ah}$ & 3.51 & 8.35 & 0.98 & 2.33 & 5.21 & 12.39 & 7.59 & 18.02 & 24.13 & 57.35 & 0.66 & 1.57 \\
\hline & A & 3.50 & 14.78 & 0.65 & 2.75 & 3.14 & 13.29 & 3.61 & 15.25 & 12.76 & 53.94 & 0.00 & 0.00 \\
\hline & $\mathrm{E}$ & 3.29 & 16.94 & 0.65 & 3.36 & 3.15 & 16.25 & 2.63 & 13.57 & 9.68 & 49.88 & 0.00 & 0.00 \\
\hline \multirow{3}{*}{ Sawit 1} & $\mathrm{Ah}$ & 6.21 & 4.95 & 3.94 & 3.14 & 6.74 & 5.37 & 66.57 & 53.05 & 37.94 & 30.24 & 4.08 & 3.25 \\
\hline & A & 6.37 & 8.54 & 1.18 & 1.59 & 8.32 & 11.15 & 20.62 & 27.66 & 36.87 & 49.46 & 1.19 & 1.60 \\
\hline & $\mathrm{E}$ & 5.37 & 10.62 & 1.18 & 2.34 & 6.16 & 12.17 & 14.05 & 27.77 & 23.22 & 45.91 & 0.60 & 1.18 \\
\hline \multirow{3}{*}{ Sawit 2} & $\mathrm{Ah}$ & 4.03 & 7.69 & 2.74 & 5.24 & 2.88 & 5.50 & 15.19 & 29.00 & 26.27 & 50.16 & 1.26 & 2.41 \\
\hline & A & 4.55 & 9.34 & 1.18 & 2.41 & 4.83 & 9.92 & 8.01 & 16.46 & 29.53 & 60.65 & 0.59 & 1.22 \\
\hline & $\mathrm{E}$ & 3.21 & 9.10 & 1.82 & 5.16 & 0.72 & 2.05 & 7.27 & 20.61 & 21.63 & 61.30 & 0.63 & 1.78 \\
\hline \multirow[t]{3}{*}{ Sawit 3} & Ah & 6.86 & 15.18 & 1.32 & 2.91 & 7.32 & 16.22 & 7.64 & 16.92 & 21.35 & 47.29 & 0.66 & 1.47 \\
\hline & A & 5.61 & 17.72 & 0.64 & 2.03 & 4.04 & 12.77 & 6.48 & 20.48 & 14.88 & 47.00 & 0.00 & 0.00 \\
\hline & $\mathrm{E}$ & 3.77 & 17.79 & 2.68 & 12.66 & 2.38 & 11.23 & 6.76 & 31.87 & 4.91 & 23.17 & 0.70 & 3.28 \\
\hline
\end{tabular}

Rerata fraksi P di lahan hutan dan sawit pada kedalaman $\pm 0-30 \mathrm{~cm}$ disajikan dalam Tabel 3. Berdasarkan Tabel 3 persentase fraksi $\mathrm{P}$ labil yaitu resin- $\mathrm{P}_{\mathrm{i}}, \mathrm{NaHCO}_{3}-\mathrm{P}_{\mathrm{i}},-\mathrm{P}_{\mathrm{o}}$ di hutan sedikit lebih tinggi dibandingkan di sawit. Hal ini mengidentifikasikan bahwa setelah lahan hutan dibuka menjadi sawit secara alami mulai terjadi sedikit penurunan fraksi P labil. Hal ini diduga karena setelah lahan dibuka terjadi erosi, mineralisasi bahan organik, dan P diangkut oleh hasil panen (Maranguit et al., 2017). Selain itu pengambilan contoh tanah pada lahan perkebunan kelapa sawit yang dilakukan di gawangan hidup bukan di piringan mengakibatkan pengaruh pemupukan P sangat sedikit. Pada tanah hutan fraksi P labil tersebut berasal dari dekomposisi bahan organik yang kemudian menyumbangkan $\mathrm{P}$ ke tanah.

Tabel 3 Rerata fraksi P di lahan hutan dan perkebunan kelapa sawit pada kedalaman $\pm 0-30 \mathrm{~cm}$

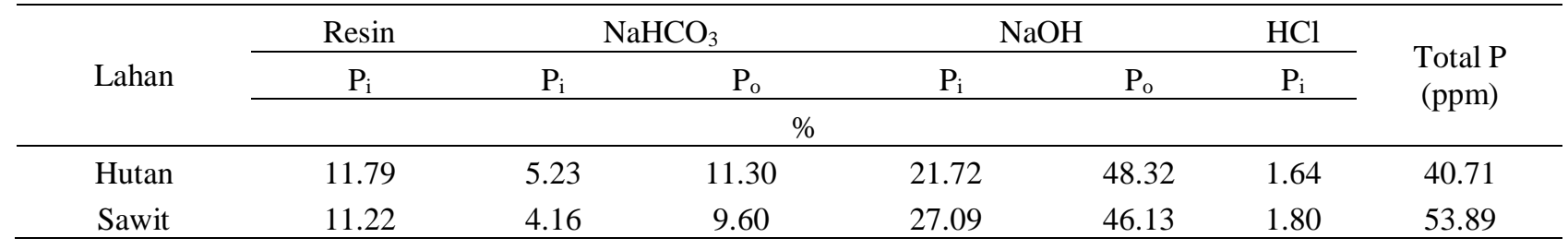




\section{Fraksi P Agak Labil}

Fraksi $\mathrm{P}$ agak labil merupakan fraksi $\mathrm{P}$ yang kurang tersedia bagi tanaman, terdiri dari fraksi yang diekstraksi dengan $\mathrm{NaOH}$ dan $\mathrm{HCl}$. Berdasarkan Tabel 2 pada umumnya setiap titik profil tanah hutan dan sawit memiliki persentase $\mathrm{NaOH}-\mathrm{P}_{\mathrm{o}}$ yang lebih tinggi dibandingkan fraksi $\mathrm{P}$ lain. Hal tersebut menunjukkan bahwa dalam penelitian ini $\mathrm{NaOH}-\mathrm{P}_{\mathrm{o}}$ merupakan fraksi $\mathrm{P}$ dominan sedangkan $\mathrm{HCl}-\mathrm{P}_{\mathrm{i}}$ merupakan fraksi $\mathrm{P}$ dengan persentase terkecil dibanding fraksi $\mathrm{P}$ lainnya. Konsentrasi (ppm) $\mathrm{NaOH}-\mathrm{P}_{\mathrm{i}}, \mathrm{P}_{\mathrm{o}}$ dan $\mathrm{HCl}-\mathrm{P}_{\mathrm{i}}$ pada lahan hutan menurun dengan kedalaman tanah pada semua titik profil, sedangkan pada lahan sawit cenderung fluktuatif.

Fraksi P didominasi oleh $\mathrm{NaOH}-\mathrm{P}_{\mathrm{o}}$ menunjukkan bahwa $\mathrm{P}$ di lahan hutan maupun sawit terakumulasi dalam bentuk $\mathrm{NaOH}-\mathrm{P}_{\mathrm{o}}$. Pola siklus $\mathrm{P}$ di hutan bergantung pada serasah yang jatuh ke lantai hutan (Maharjan et al., 2018). Serasah kemudian terdekomposisi dan menghasilkan senyawa humat dan fulvat yang berikatan dengan $\mathrm{P}$ dan menjadikan $\mathrm{P}$ organik yang agak labil $\left(\mathrm{NaOH}-\mathrm{P}_{\mathrm{o}}\right)$. Tidak adanya proses pengolahan lahan (pembalikan tanah) di lahan hutan menyebabkan bahan organik yang jatuh cenderung terkonsentrasi di permukaan tanah. Menurunnya kandungan C-organik dalam tanah menyebabkan konsentrasi NaOH- $\mathrm{P}_{\mathrm{o}}$ menurun seiring dengan bertambahnya kedalaman tanah yang sebelumnya telah dilaporkan dalam penelitian Rodrigues et al. (2015). Pada lahan sawit $\mathrm{P}_{\mathrm{o}}$ berasal dari rumput-rumput dan serasah sawit di sekitarnya.

Fraksi $\mathrm{P}_{\mathrm{i}}$ tertinggi dalam penelitian ini adalah fraksi agak labil yang diekstrak dengan $\mathrm{NaOH}\left(\mathrm{NaOH}-\mathrm{P}_{\mathrm{i}}\right)$. Tingginya fraksi $\mathrm{P}$ tersebut menunjukkan bahwa $\mathrm{P}$ dalam larutan tanah dengan sangat cepat dierap oleh hidrusoksida Al dan Fe dalam jumlah besar menjadi bentuk Al-P dan Fe-P yang agak labil (Hou et al., 2014). Persentase fraksi $\mathrm{P}$ terendah ditunjukkan $\mathrm{HCl}-\mathrm{P}_{\mathrm{i}}$ karena tanah dalam penelitian ini mempunyai reaksi sangat masam sampai masam. Hou et al. (2014) dan Tiecher et al. (2018) melaporkan bahwa tanah sangat masam sampai masam memiliki konsentrasi fraksi $\mathrm{HCl}_{\mathrm{P}}$ yang rendah. Dalam penelitian Alovisi et al. (2019) menemukan bahwa peningkatan pupuk tidak sejalan dengan bertambahnya fraksi $\mathrm{HCl}-\mathrm{P}_{\mathrm{i}}$ di tanah masam yang mengidentifikasikan bahwa sangat sedikit pupuk yang terakumulasi dalam fraksi ini.

Untuk membandingkan fraksi $\mathrm{P}$ agak labil secara keseluruhan pada kedalaman $\pm 0-30 \mathrm{~cm}$ antara lahan hutan dan sawit disajikan perbandingan rerata persentase fraksi $\mathrm{P}$ agak labil pada Tabel 3. Berdasarkan Tabel 3 persentase $\mathrm{NaOH}-\mathrm{P}_{\mathrm{o}}$ di hutan lebih tinggi dibandingkan dengan di sawit, sebaliknya $\mathrm{NaOH}-\mathrm{P}_{\mathrm{i}}$ di sawit lebih tinggi dibandingkan dengan di hutan. Artinya pembukaan lahan sawit secara alami mengakibatkan perubahan distribusi fraksi $\mathrm{P}$ di tanah karena adanya perubahan dari kandungan C-organik tanah. Hal yang sama ditemukan dalam penelitian Maranguit et al. (2017). Pembukaan lahan sawit menyebabkan penurunan nilai $\mathrm{NaOH}-\mathrm{P}_{\mathrm{o}}$ sebagai akibat dari bahan organik yang termineralisasi. Hal tersebut mengakibatkan bentuk $\mathrm{P}_{\mathrm{o}}$ ditransformasi menjadi bentuk $\mathrm{NaOH}-\mathrm{P}_{\mathrm{i}}$ yang sulit melepaskan $\mathrm{P}$ bagi tanaman karena terikat relatif kuat oleh Fe dan Al hidrusoksida di tanah. Transformasi dari fraksi P organik pada contoh tanah dari perkebunan kelapa sawit menjadi $\mathrm{NaOH}-\mathrm{P}_{\mathrm{i}}$ tersebut ditunjukkan dengan persentasenya yang lebih besar dibandingkan contoh tanah hutan (Tabel 3). Selain itu peningkatan NaOH-P $\mathrm{P}_{\mathrm{i}}$ mungkin juga disebabkan karena adanya pengaruh pemupukan $\mathrm{P}$ yang berasal dari piringan masuk ke gawangan. Pada contoh tanah dari hutan, $\mathrm{NaOH}-\mathrm{P}_{\mathrm{o}}$ memiliki persentase tertinggi karena bahan organik di hutan lebih tinggi, berasal dari vegetasi yang padat dan beragam. Semakin tinggi jumlah biomassa maka akan semakin tinggi pula kandungan karbon (Istomo dan Farida, 2017). Hal ini dikonfirmasi dengan kadar C-organik di hutan lebih besar dibandingkan dengan di sawit (Gambar 3). Maranguit et al. (2017) menyatakan bahwa pada tanah hutan tropis P ditemukan dominan berada dalam bentuk organik. 


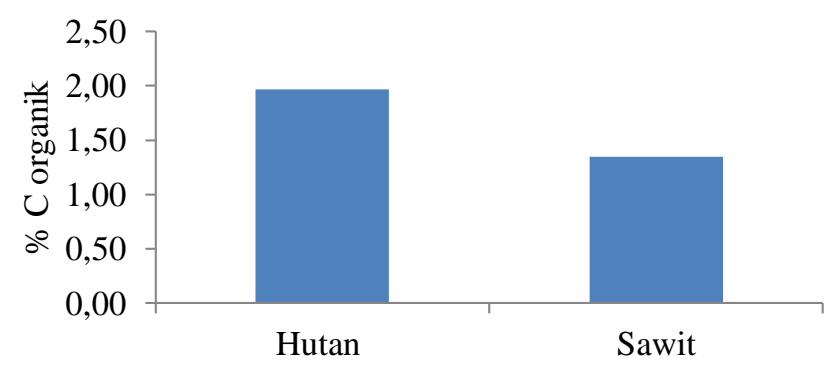

Gambar 3 Rerata C-organik di lahan hutan dan perkebunan kelapa sawit

\section{Korelasi Fraksi P dengan Sifat Kimia Tanah Terpilih}

Hasil korelasi antara fraksi P dengan sifat kimia tanah terpilih disajikan dalam Tabel 4. Korelasi negatif yang signifikan terjadi antara $\mathrm{pH}$ dengan fraksi $\mathrm{NaHCO}_{3}-\mathrm{P}_{\mathrm{o}}$ dan $\mathrm{NaOH}-\mathrm{P}_{\mathrm{o}}$ pada lahan hutan. Hal tersebut menunjukkan bahwa semakin kecil $\mathrm{pH}$ tanah maka semakin tinggi konsentrasi dari kedua fraksi tersebut. Rhoton dan Bigham (2005) melaporkan bahwa pada $\mathrm{pH}$ rendah, Al dan Fe hidrusoksida efisien dalam mengabsorbsi P dalam tanah dan ini terkait dengan NaOH-P. Selanjutnya Alt et al. (2011) mengemukakan bahwa tidak seharusnya terjadi korelasi negatif $\mathrm{pH}$ dengan $\mathrm{P}_{\mathrm{i}}$ labil pada tanah dengan $\mathrm{pH}$ rendah, karena pada keadaan tersebut $\mathrm{P}$ diendapkan dengan $\mathrm{Al}$ fosfat $(\mathrm{NaOH}-\mathrm{P})$. Sehingga diduga pengendapan $\mathrm{P}$ ini dihambat oleh tingkat kompleksasi yang tinggi dari Al terlarut di dalam tanah pada tanah yang tinggi kandungan bahan organiknya (Alt et al., 2011). Selain itu persaingan adsorpsi dengan anion lain (sulfat) juga dapat terjadi (Parfitt, 1982).

Tabel 4 Korelasi Pearson fraksi P dengan sifat kimia tanah terpilh pada penggunaan lahan hutan dan perkebunan kelapa sawit

\begin{tabular}{|c|c|c|c|c|c|c|c|}
\hline Lahan & Fraksi P & $\mathrm{pH} \mathrm{H} \mathrm{H}_{2} \mathrm{O}$ & C-organik & $\mathrm{Fe}_{\mathrm{d}}$ & $\mathrm{Al}_{\mathrm{d}}$ & $\mathrm{Fe}_{\mathrm{o}}$ & $\mathrm{Al}_{\mathrm{o}}$ \\
\hline \multirow[t]{6}{*}{ Hutan } & Resin & -0.432 & $0.903 * *$ & -0.188 & 0.406 & 0.179 & 0.368 \\
\hline & $\mathrm{NaHCO}_{3}-\mathrm{P}_{\mathrm{i}}$ & 0.075 & 0.471 & -0.073 & 0.566 & 0.381 & 0.230 \\
\hline & $\mathrm{NaHCO}_{3}-\mathrm{P}_{\mathrm{o}}$ & $-0.678 *$ & $0.830 * *$ & -0.309 & 0.167 & -0.152 & 0.217 \\
\hline & $\mathrm{NaOH}-\mathrm{P}_{\mathrm{i}}$ & -0.302 & 0.708* & -0.266 & 0.552 & 0.074 & 0.162 \\
\hline & $\mathrm{NaOH}-\mathrm{P}_{\mathrm{o}}$ & $-0.672 *$ & $0.777 *$ & -0.508 & 0.301 & -0.106 & -0.133 \\
\hline & $\mathrm{HCl}-\mathrm{P}_{\mathrm{i}}$ & -0.404 & $0.752 *$ & -0.277 & 0.505 & 0.195 & 0.147 \\
\hline \multirow[t]{6}{*}{ Sawit } & Resin & -0.508 & 0.639 & 0.054 & 0.339 & -0.332 & 0.142 \\
\hline & $\mathrm{NaHCO}_{3}-\mathrm{P}_{\mathrm{i}}$ & 0.390 & 0.516 & -0.046 & -0.434 & -0.015 & -0.224 \\
\hline & $\mathrm{NaHCO}_{3}-\mathrm{P}_{\mathrm{o}}$ & -0.401 & 0.539 & 0.312 & 0.421 & -0.049 & 0.424 \\
\hline & $\mathrm{NaOH}-\mathrm{P}_{\mathrm{i}}$ & 0.337 & 0.711* & 0.306 & -0.106 & 0.064 & 0.095 \\
\hline & $\mathrm{NaOH}-\mathrm{P}_{\mathrm{o}}$ & 0.454 & 0.355 & 0.553 & -0.091 & 0.540 & 0.453 \\
\hline & HCl-P & 0.385 & $0.716^{*}$ & 0.231 & -0.227 & 0.075 & 0.021 \\
\hline
\end{tabular}

* korelasi nyata pada taraf $0.05 ; * *$ korelasi nyata pada taraf 0.01

Berdasarkan Tabel 4, pada lahan hutan terdapat korelasi positif signifikan antara C-organik dengan resin$\mathrm{P}_{\mathrm{i}}, \mathrm{NaHCO}_{3}-\mathrm{P}_{\mathrm{o}}, \mathrm{NaOH}-\mathrm{P}_{\mathrm{i}}, \mathrm{P}_{\mathrm{o}}$, dan $\mathrm{HCl}-\mathrm{P}_{\mathrm{i}}$. Pada lahan sawit $\mathrm{C}$-organik berkorelasi positif dan nyata dengan $\mathrm{NaOH}-\mathrm{P}_{\mathrm{i}}$ dan $\mathrm{HCl}-\mathrm{P}_{\mathrm{i}}$. Artinya semakin tinggi $\mathrm{C}$-organik maka semakin tinggi pula fraksi $\mathrm{P}$ tersebut di tanah. $\mathrm{Hal}$ ini mengidentifikasikan bahwa $\mathrm{C}$-organik berperan penting atau mengontrol fraksi $\mathrm{P}$ tanah pada lapisan atas. Hal yang sama telah ditemukan dalam penelitian sebelumnya (Parjono et al., 2019; Qian et al., 2017; Maranguit et al., 2017). Satu-satunya sumber P pada lahan hutan hanya berasal dari bahan organik. Maharjan 
et al. (2018) mengemukakan bahwa bahan organik merupakan sumber $\mathrm{P}_{\mathrm{o}}$ yang sangat penting sebagai pasokan $\mathrm{P}$ di tanah tropis. Cadangan $\mathrm{P}$ alam berkurang setelah adanya pembukaan lahan hutan (Maranguit et al., 2017). Tiessen et al. (1994) menambahkan bahwa tanah dengan tingkat pelapukan tinggi memiliki P tersedia yang rendah dan bergantung pada mineralisasi $\mathrm{P}_{\mathrm{o}}$ sehingga penting dalam mempertahankan bahan organik dalam menjaga kesuburan tanah. Fraksi $\mathrm{P}_{\mathrm{o}}$ dalam tanah sangat baik dalam menjaga produktivitas tanah jangka panjang.

Korelasi positif tertinggi $(\mathrm{r}=0.903)$ terjadi antara resin- $\mathrm{P}_{\mathrm{i}}$ dengan $\mathrm{C}$-organik di lahan hutan. Hubungan yang kuat tersebut juga dilaporkan oleh Johnson et al. (2003). Resin- $P_{i}$ yang sangat tersedia tersebut berasal dari $\mathrm{P}_{\mathrm{o}}$ dengan bantuan mikroba pendekomposisi (Tiessen et al., 1994). Dengan semakin meningkatnya Corganik maka mikroba memperoleh lebih banyak energi dan sumber $\mathrm{C}$ untuk membentuk struktur tubuhnya, sehingga akan semakin tinggi pula produksi enzim fosfatase yang berperan dalam mineralisasi $\mathrm{P}$ (Allison dan Vitousek, 2005). Berdasarkan korelasi pada Tabel 4 mengindikasikan bahwa ketika hutan dibuka menjadi perkebunan kelapa sawit dan dibandingkan tanahnya (kedalaman \pm 0-30 cm) antara hutan dan sawit yang tidak dipupuk secara langsung maka keberadaan $\mathrm{P}$ dikontrol oleh C-organik. Selanjutnya ketika C-organik hilang maka yang mengontrol fraksi $\mathrm{P}$ di tanah adalah $\mathrm{Al}$ dan Fe hidrusoksida (Hartono et al., 2006) meskipun dalam penelitian ini tidak menunjukkan adanya korelasi yang signifikan diduga karena nilai Al dan Fe tiap titik profil tanah di lahan hutan dan sawit relatif sama (Tabel 1). Oleh karena itu, pengetahuan umum mengenai keberadaan hidrusoksida Al dan Fe mengontrol fraksi P pada tanah masam (Hartono et al., 2006) tidak terjadi pada lapisan olah tanah dalam penelitian ini. Kajian fraksi $\mathrm{P}$ pada lapisan olah tanah dalam penelitian ini menemukan bahwa C-organik mengontrol distribusi $\mathrm{P}$ pada lapisan olah tanah hutan dan perkebunan kelapa sawit.

\section{SIMPULAN}

Penurunan C-organik setelah lahan hutan dikonversi ke sawit pada penelitian ini terjadi pada lapisan atas. Kandungan C-organik lapisan atas yang lebih tinggi di lahan hutan dibandingkan dengan lahan di perkebunan kelapa sawit mempengaruhi distribusi fraksi $\mathrm{P}$ tanah di lapisan atas kedua tipe lahan tersebut.

Persentase fraksi resin- $\mathrm{P}_{\mathrm{i}}, \mathrm{NaHCO}_{3}-\mathrm{P}_{\mathrm{i}}$ dan $-\mathrm{P}_{\mathrm{o}}$ yang merupakan fraksi yang tersedia (labil) ditemukan lebih besar pada lahan hutan daripada perkebunan kelapa sawit. NaOH-P yang merupakan bentuk $\mathrm{P}$ agak labil dalam bentuk $\mathrm{P}$ organik merupakan fraksi yang dominan baik di hutan maupun di perkebunan kelapa sawit. Persentase $\mathrm{NaOH}-\mathrm{P}_{\mathrm{i}}$ yang merupakan bentuk $\mathrm{P}$ agak labil dalam bentuk $\mathrm{P}$ inorganik di lahan perkebunan kelapa sawit lebih tinggi dibandingkan dengan di hutan menunjukkan telah terjadi transformasi dari bentuk $\mathrm{P}$ organik ke $\mathrm{P}$ inorganik karena penurunan kandungan C-organik.

Analisis korelasi menunjukkan bahwa hampir semua fraksi $\mathrm{P}$ berkorelasi positif yang signifikan dengan C-organik, artinya semakin tinggi kandungan C-organik maka semakin tinggi pula fraksi $\mathrm{P}$. Hal ini menunjukkan bahwa C-organik tanah mengontrol distribusi fraksi P pada lapisan permukaan tanah di lahan hutan dan perkebunan kelapa sawit.

\section{DAFTAR PUSTAKA}

[BPS] Badan Pusat Statistik. 2018. Statistik Kelapa Sawit Indonesia 2018. Jakarta (ID).

Allison SD, Vitousek PM. 2005. Responses of extracellular enzymes to simple and complex nutrient inputs. Soil Biol. Biochem. 37: 937-944. doi: 10.1016/j.soilbio.2004.09.014.

Alovisi AMT, Alovisi AA, Serra AP, Tokura LK, Davide LMC, Lourente ERP, Silva RSD, Tokura WI, Souza DAD, Mar GDD. 2019. Phosphorus fractions and their transformations in Entisol. J. Agric. Sci. 11(1): 485-493. doi: 10.5539/jas.v11n1p485.

Alt F, Oelmann Y, Herold N, Schrumpf M, Wilcke W. 2011. Phosphorus partitioning in grassland and forest soils of Germany as related to land-use type, management intensity, and land use-related $\mathrm{pH}$. J. Plant Nutr. Soil Sci. 174: 195-209. doi: 10.1002/jpln.201000142. 
Chang SC, Jackson ML. 1957. Fractionation of soil phosphorus. Soil Sci. 84: 133-134.

Drescher J, Rembold K, Allen K, Beckschafer P, Buchori D, Clough Y, Faust H, Fauzi AM, Gunawan D, Hertel D, et al. 2016. Ecological and socio-economic functions across tropical land use systems after rainforest conversion. Phil. Trans. R. Soc. B. 371: 20150275. doi: 10.1098/rstb.2015.0275.

Hanum C, Rauf A, Nasution I, Fazrin DA, Habibi AR. 2016. Nitrogen, phosphor, and potassium level in soil and oil palm tree at various composition of plant species mixtures grown. IOP Conf. Ser.: Earth Environ. Sci. 41 012008. doi: 10.1088/1755-1315/41/1/012008.

Hartono A, Funakawa S, Kosaki T. 2005. Phosphorus sorption-desorption characteristics of selected acid upland soils in Indonesia. Soil Sci. Plant Nutr. 51: 787-799. doi: 10.1111/j.1747-0765.2005.tb00113.x.

Hartono A, Funakawa S, Kosaki T. 2006. Transformation of added phosphorus to acid upland soils with different soil properties in Indonesia. Soil Sci. Plant Nutr. 52: 734-744. doi: 10.1111/j.17470765.2006.00087.x.

Hedley MJ, Stewart JWB, Chauhan BS. 1982. Change in inorganic and organic soil phosphourus fraction induced by cultivation practice and by laboratory incubation. Soil Sci. Soc Am. J. 46: 970-976. doi: 10.2136/sssaj1982.03615995004600050017x.

Hou E, Chen C, Wen D, Liu X. 2014. Relationships of phosphorus fractions to organic carbon content in surface soils in mature subtropical forests, Dinghushan, China. Soil Res. 52: 55-63. doi: 10.1071/SR13204.

Istomo, Farida NE. 2017. Potensi simpanan karbon di atas permukaan tanah tegakan Acacia nilotica L. (Willd) ex. Del. di Taman Nasional Baluran, Jawa Timur. JPSL. 7(2): 155-162. doi: 10.19081/jpsl.2017.7.2.155.

Johnson AH, Frizano J, Vann DR. 2003. Biogeochemical implications of labile phosphorus in forest soils determined by the Hedley fractionation procedure. Oecologia. 135: 487-499. doi: 10.1007/s00442-0021164-5.

Maharjan M, Maranguit D, Kuzyakov Y. 2018. Phosphorus fractions in subtropical soils depending on land use. Eur. J. Soil Biol. 87: 17-24. doi: 10.1016/j.ejsobi.2018.04.002.

Maranguit D, Guillaume T, Kuzyakov Y. 2017. Land-use change affects phosphorus fractions in highly weathered tropical soils. Catena. 149: 385-393. doi: 10.1016/j.catena.2016.10.010.

McKeague JA, Day JH. 1966. Dithionite and oxalate extractable $\mathrm{Fe}$ and $\mathrm{Al}$ as aids in differentiating various classes of soils. Can. J. Soil Sci. 46: 13-22. doi: 10.4141/cjss66-003.

Mehra PO, Jackson ML. 1960. Iron oxide removal from soils and clays by dithionite-citrate system buffered with sodium bicarbonate. Clays Clay Miner. 7: 317-327. doi: 10.1016/B978-0-08-009235-5.50026-7.

Parfitt RL. 1982. Competitive adsorption of phosphate and sulphate on goethite (a-FeOOH): a note. New Zealand J. Sci. 25: 147-148.

Parjono, Anwar S, Murtilaksono K, Indriyati LT. 2019. Fraksionasi fosfor pada profil tanah hutan, wanatani, dan tegalan di Jawa Barat. JIPI. 24(4): 319-326. doi: 10.18343/jipi.24.4.319.

Putra GS, Hartono A, Syaiful A, Murtilaksono K. 2019. Hubungan kation-anion dalam pergerakan dan pencucian hara pada tanah. JPSL. 9(4): 960-969. doi: 10.29244/jps1.9.4. 960-969.

Qian J, Shen M, Wang P, Wang C, Li K, Liu J, Tian X, Lu B. 2017. Fractions and spatial distributions of agricultural riparian soil phosphorus in a small river basin of Taihu area, China. Chem. Spec. Bioavailab. 29(1): 33-41. doi: 10.1080/09542299.2017.1286951.

Rhoton FE, Bigham JM. 2005. Phosphate adsorption by ferrihydrite-amended soils. J. Environ. Qual. 34: 890896. doi: 10.2134/jeq2004.0176.

Rodrigues M, Pavinato PS, Withers PJA, Teles APB, Herrera WFB. 2015. Legacy phosphorus and no tillage agriculture in tropical oxisols of the Brazilian savanna. Sci. Total Environ. 542(Part B): 1050-1061. doi: 10.1016/j.scitotenv.2015.08.118.

Schroth G, Angelo SAD, Teixeira WG, Haag D, Lieberei R. 2002. Conversion of secondary forest into agroforestry and monoculture plantation in Amazonia: consequences for biomass, litter and soil carbon stocks after 7 years. Forest Ecol. Manag. 163: 131-150. doi: 10.1016/S0378-1127(01)00537-0. 
Subagyo H, Suharta N, Agus. B. Siswanto. 2000. Tanah-tanah pertanian di Indonesia. Di dalam: Pusat Penelitian Tanah dan Agroklimat (Indonesia). Sumberdaya Lahan Indonesia dan Pengelolaannya. Bogor (ID): Pusat Penelitian Tanah dan Agroklimat.

Tiecher T, Gomes MV, Ambrosini VG, Amorim MB, Bayer C. 2018. Assessing linkage between soil phosphorus forms in contrasting tillage systems by path analysis. Soil Till. Res. 175: 276-280. doi: 10.1016/j.still.2017.09.015.

Tiessen H, Cuevas E, Chacon P. 1994. The role of soil organic matter in sustaining soil fertility. Nature. 371 : 783-785. doi: 10.1038/371783a0.

Tiessen H, Moir JO. 1993. Characterization of available P by sequential extraction. Di dalam: Carter MR, Gregorich EG, editor. Soil Sampling and Methods of Analysis. Boca Raton (US): CRC Press. 